\title{
DESAIN PEMASARAN ONLINE BERBASIS WEB UNTUK PEMASARAN PRODUK KERAJINAN KERANG MUTIARA DI KOTA AMBON (STUDI KASUS: PONDOK MUTIARA)
}

\author{
J. M. Tupan \\ e-mail : johantupan@yahoo.com \\ Program Studi Teknik Industri Universitas Pattimura - Ambon
}

\begin{abstract}
ABSTRAK
Website adalah sebuah kumpulan dari halaman web yang saling berhubungan dan dapat diakses melalui halaman depan (home page) menggunakan sebuah browser. Sekarang ini sudah banyak perusahaan yang memanfaatkan jaringan internet dan menggunakan website sebagai media promosi dan toko online untuk menjual produk perusahaan tersebut. Website toko online biasanya memanfaatkan sistem e-commerce. Electronic Commerce (E-Commerce) didefinisikan sebagai proses pembelian dan penjualan produk, jasa dan informasi yang dilakukan secara elektronik dengan memanfaatkan jaringan komputer. Salah satu jaringan yang digunakan adalah internet. E-commerce dapat mempermudah pemasaran produk yang ingin dijual. Dengan adanya e-commerce, Pembayaran dapat dilakukan secara online dan pastinya memudahkan para pembeli. Sistem e-commerce yang digunakan adalah Wordpess dengan mengandalkan plugin WooCommerce yang menyediakan fitur-fitur sebuah web e-commerce. Penelitian yang dilakukan adalah untuk meendesain sebuah website toko online yang juga menyediakan sistem e-commerce di dalamnya.
\end{abstract}

Kata kunci : website, e-commerce, woocommerce.

\section{PENDAHULUAN}

Laporan Tahunan Dinas Koperasi dan UMKM Provinsi Maluku (2012) menyebutkan bahwa jumlah UMKM di provinsi ini mencapai 6.242 unit usaha, yang terdiri atas 3.282 unit usaha mikro, 3.253 uni usaha kecil dan 89 unit usaha menengah. Berdasarkan Rencana Strategik Dinas Perindustrian Kota Ambon tahun 2006, diketahui jumlah kelompok industri kerajinan (formal) di kota Ambon berjumlah 30 unit usaha dengan nilai investasi sebesar Rp. 1.269.000.000 dengan jumlah tenaga kerja 171 orang. Salah satu hasil industri kerajinan asli Provinsi Maluku yang saat ini sementara diminati oleh masyarakat adalah industri kerajinan kerang mutiara dan merupakan salah satu produk unggulan Propinsi Maluku terlebih khusus Kota Ambon. Industri ini telah ada dan berkembang di kota Ambon namun keberadaannya belum memberikan sumbangan yang nyata terhadap ekonomi daerah. Hal ini dibuktikan dengan hanya sebesar 3 buah (10\%) unit usaha formal dengan 40 tenaga kerja dari 30 unit usaha industri kerajinan yang berada di kota Ambon. (Anonimous, 2006).

Salah satu home industry di kota Ambon yang bergerak di bidang kerajinan kerang-kerangan mutiara adalah Pondok Mutiara, yang merupakan objek dalam kegiatan penelitian ini. Industri kerajinan kerang mutiara di Desa Batu Merah sudah berlangsung sejak lama dan dilakukan secara turun temurun. Sudah puluhan tahun dan turun temurun para pengrajin di Negeri Batu Merah Ambon mengolah cangkang kerang mutiara menjadi produk seni. Kerajinan kerang mutiara ini merupakan oleholeh primadona khas Maluku selain produk kain tenun, minyak kayu putih, dan sagu. Keindahan kerajinan kerang ini dapat ditemukan dalam bentuk produk yang terlihat pada tabel 1 .

\begin{tabular}{|c|c|c|c|c|c|c|}
\hline \multicolumn{2}{|c|}{$\begin{array}{r}\text { Tabel 1. Jumlah } \\
\text { Mutiara }\end{array}$} & \multicolumn{4}{|c|}{ Kerajinan } & Kerang \\
\hline \multirow[t]{2}{*}{ No } & \multirow[t]{2}{*}{ Prodrix. } & \multicolumn{5}{|c|}{ 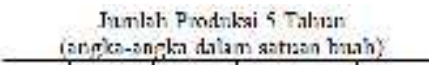 } \\
\hline & & 20118 & 20102 & 2010 & 21111 & 2.712 \\
\hline$T$ & Trikisan Alam & 48 & 60 & 72 & 39 & 39 \\
\hline 2 & Flore & 18 & 60 & 60 & 37 & 38 \\
\hline 3 & Fatide & 60 & 96 & 108 & 62 & 51 \\
\hline 4 & Gambar Religi Kriator & 48 & 60 & $6 \hat{\mathrm{f}}$ & 50 & 48 \\
\hline 5 & Kaligrat: & 37 & 50 & 62 & 44 & 44 \\
\hline 6 & Tashil & 22 & 24 & 24 & 24 & 24 \\
\hline 7 & Gilany & 21 & 21 & $\$ 7$ & 22 & 22 \\
\hline$s$ & Pist & 12 & 1 & 22 & 22 & 18 \\
\hline 9 & Lugu & 12 & 21 & 22 & 22 & 28 \\
\hline 10 & Papan Nama & 24 & 24 & 24 & 14 & 14 \\
\hline 11 & Kancira Jas & 12 & 14 & 14 & 14 & 14 \\
\hline 12 & Bivs & 85 & 96 & 108 & 60 & 50. \\
\hline & Jimalsh & 132 & 536 & 615 & 110 & 993 \\
\hline
\end{tabular}

Produksi kerajinan kerang mutiara dari tahun 2008-2012 berfluktuatif namun cenderung menurun hanya pada tahun 2010 mengalami peningkatan karena banyak wisatawan yang berkunjung ke Ambon pada saat sedang berlangsung kegiatan sail Banda. Departemen Perdagangan Republik Indonesia (2009) yang memperkarsai kegiatan inisiatif pengembangan industri kreatif di Indonesia telah mengidentifikasi salah satu permasalahan utama yang perlu diagendakan pemecahannya yaitu lambatnya upaya mengakselerasi tumbuhnya teknologi informasi dan komunikasi terkait dengan pengembangan akses pasar dan inovasi industri kreatif. Teknologi informasi sangat berpengaruh terhadap pekerjaan maupun bisnis dalam segala bidang, tidak terkecuali untuk industri kerajina kerang muatiara di kota Ambon. 
Sistem pemasaran produk kerajinan kerang mutiara pada Pondok Mutiara ini masilah tergolong manual dan tradisional dimana barang yang selesai dikerjakan dipasarkan hanya melalui toko penjualan yang ada di daerah sekitar, selain itu promosi hanya dilakukan jika ada pameran yang diselenggarakan oleh pemerintah kota Ambon, namun sayangnya belum cukup meningkatkan jumlah hasil penjualan dan belum dapat bersaing dengan usaha-usaha yang lain dalam bidang yang sama.

Mengacu pada kondisi aktual diatas untuk dapat meningkatkan persaingan maka solusi yang ditawarkan adalah melakukan promosi melalui media online. Oleh karena itu maka dipandang perlu untuk dilakukan kegitan penelitian tentang membangun dan mendesain website online bagi pengrajin kerang mutiara pada Pondok Mutiara yang nantinya digunakan sebagai media promosi dan penjualan online

\section{KAJIAN TEORI DAN METODE Pengertian Sistem}

Pengertian sistem secara umum adalah suatu paduan yang terdiri dari beberapa unsur yang tergabung satu sama lain agar mempermudah laju aliran informasi, energi ataupun materi hingga dapat mencapai tujuan tertentu.

Sistem dapat dijumpai di dalam bidang ilmu apa pun karena menjadi cara menggambarkan interaksi suatu set entitas yang paling mudah. Termasuk membuat suatu model matematika yang rumit menjadi lebih sederhana.

\section{Pengertian Informasi}

Informasi adalah pesan (ucapan atau ekspresi) atau kumpulan pesan yang terdiri dari order sekuens dari simbol, atau makna yang dapat ditafsirkan dari pesan atau kumpulan pesan. Informasi dapat direkam atau ditransmisikan. Hal ini dapat dicatat sebagai tanda-tanda, atau sebagai sinyal berdasarkan gelombang. Informasi adalah jenis acara yang mempengaruhi suatu negara dari sistem dinamis. Para konsep memiliki banyak arti lain dalam konteks yang berbeda.

\section{Pengertian Sistem Informasi}

Sistem Informasi (SI) adalah kombinasi dari teknologi informasi dan aktivitas orang yang menggunakan teknologi itu untuk mendukung operasi dan manajemen. Dalam arti yang sangat luas, istilah sistem informasi yang sering digunakan merujuk kepada interaksi antara orang, proses algoritmik, data, dan teknologi. Dalam pengertian ini, istilah ini digunakan untuk merujuk tidak hanya pada penggunaan organisasi teknologi informasi dan komunikasi (TIK), tetapi juga untuk cara di mana orang berinteraksi dengan teknologi ini dalam mendukung proses bisnis.

\section{Pengertian Website}

Website adalah halaman informasi yang disediakan melalui jalur internet sehingga bisa diakses di seluruh dunia selama terkoneksi dengan jaringan internet. Website merupakan komponent atau kumpulan komponen yang terdiri dari teks, gambar, suara animasi sehingga lebih merupakan media informasi yang menarik untuk dikunjungi. Secara garis besar, Website bisa digolongkan menjadi 3 bagian yaitu:

1. Website Statis

2. Website Dinamis

3. Website Interaktif

Sebuah situs web (sering pula disingkat menjadi situs saja; web site, site) adalah sebutan bagi sekelompok halaman web (web page), yang umumnya merupakan bagian dari suatu nama domain (domain name) atau subdomain di World Wide Web (WWW) di Internet. WWW terdiri dari seluruh situs web yang tersedia kepada publik. Halaman-halaman sebuah situs web diakses dari sebuah URL yang menjadi "akar" (root), yang disebut homepage (halaman induk sering diterjemahkan menjadi "beranda", "halaman muka"), dan biasanya disimpan dalam server yang sama. Tidak semua situs web dapat diakses dengan gratis. Beberapa situs web memerlukan pembayaran agar dapat menjadi pelanggan, misalnya situs-situs yang menampilkan pornografi, situs-situs berita, layanan surat elektronik (e-mail), dan lain-lain.

Secara terminologi, Website adalah kumpulan dari halaman-halaman situs, yang biasanya terangkum dalam sebuah domain atau subdomain, yang tempatnya berada di dalam World Wide $W e b(W W W)$ di Internet. Sebuah halaman web adalah dokumen yang ditulis dalam format $H T M L$ (Hyper Text Markup Language), yang hampir selalu bisa diakses melalui HTTP, yaitu protokol yang menyampaikan informasi dari server Website untuk ditampilkan kepada para pemakai melalui web browser. Semua publikasi dari Website-Website tersebut dapat membentuk sebuah jaringan informasi yang sangat besar.

Halaman-halaman dari Website akan bisa diakses melalui sebuah URL yang biasa disebut Homepage. URL ini mengatur halaman-halaman situs untuk menjadi sebuah hirarki, meskipun, hyperlink-hyperlink yang ada di halaman tersebut mengatur para pembaca dan memberitahu mereka sususan keseluruhan dan bagaimana arus informasi ini berjalan.

Beberapa Website membutuhkan subskripsi (data masukan) agar para user bisa mengakses sebagian atau keseluruhan isi Website tersebut. Contohnya, ada beberapa situs-situs bisnis, situssitus e-mail gratisan, yang membutuhkan subkripsi agar kita bisa mengakses situs tersebut. 
Secara terminologi, Website adalah kumpulan dari halaman-halaman situs, yang biasanya terangkum dalam sebuah domain atau subdomain, yang tempatnya berada di dalam World Wide Web $(W W W)$ di Internet. Sebuah halaman web adalah dokumen yang ditulis dalam format HTML (Hyper Text Markup Language), yang hampir selalu bisa diakses melalui HTTP, yaitu protokol yang menyampaikan informasi dari server Website untuk ditampilkan kepada para pemakai melalui web browser. Semua publikasi dari Website-Website tersebut dapat membentuk sebuah jaringan informasi yang sangat besar.

Halaman-halaman dari Website akan bisa diakses melalui sebuah URL yang biasa disebut Homepage. URL ini mengatur halaman-halaman situs untuk menjadi sebuah hirarki, meskipun, hyperlink-hyperlink yang ada di halaman tersebut mengatur para pembaca dan memberitahu mereka sususan keseluruhan dan bagaimana arus informasi ini berjalan.

Beberapa Website membutuhkan subskripsi (data masukan) agar para user bisa mengakses sebagian atau keseluruhan isi Website tersebut. Contohnya, ada beberapa situs-situs bisnis, situssitus e-mail gratisan, yang membutuhkan subkripsi agar kita bisa mengakses situs tersebut.

\section{Woocommerce}

WooCommerce adalah sebuah plugin yang di buat oleh WooThemes. Sebuah perusahaan eCommerce yang bergerak dibidang penjualan themes khusus WordPress.

Tidak hanya menyediakan themes premium bagi WordPress, WooThemes juga menyediakan sebuah plugin yang dapat menyulap WordPress menjadi sebuah $e$-Commerce yang canggih dan memiliki fitur-fitur lengkap layaknya situs-situs $e$ Commerce besar.

Cukup dengan menginstall plugin WooCommerce ke dalam sistem WordPress dan melakukan beberapa pengaturan maka situs WordPress anda siap dijadikan online shop yang mampu melakukan transaksi otomatis.

\section{E-commerce}

Perdagangan elektronik (electronic commerce atau e-commerce) adalah penyebaran, penjualan, pembelian, pemasaran barang dan jasa yang mengandalkan sistem elektronik, seperti internet, televisi, atau jaringan komputer lainnya.

E-commerce melibatkan transfer dana dan pertukaran data elektronik, sistem manajemen dan pengumpulan data secara otomatis. E-commerce adalah salah satu bisnis yang paling sering digeluti oleh masyarakat di Indonesia karena memberikan keuntungan yang menjanjikan.

\section{Web Server}

Server atau Web Server adalah sebuah software yang memberikan layanan berbasis data dan berfungsi menerima permintaan dari HTTP atau HTTPS pada klien yang dikenal dan biasanya kita kenal dengan nama web browser (Mozilla Firefox, Google Chrome) dan untuk mengirimkan kembali yang hasilnya dalam bentuk beberapa halaman web dan pada umumnya akan berbentuk dokumen HTML.

Fungsi utama Server atau Web Server adalah untuk melakukan atau akan mentransfer berkas permintaan pengguna melalui protokol komunikasi yang telah ditentukan sedemikian rupa. halaman web yang diminta terdiri dari berkas teks, video, gambar, file dan banyak lagi. pemanfaatan Web Server berfungsi untuk mentransfer seluruh aspek pemberkasan dalam sebuah halaman web termasuk yang di dalam berupa teks, video, gambar dan banyak lagi.

Salah satu contoh dari Web Server adalah Apache. Apache (Apache Web Server - The HTTP Web Server) merupakan Web Server yang paling banyak dipergunakan di Internet. Program ini pertama kali didesain untuk sistem operasi lingkungan UNIX. Apache mempunyai program pendukung yang cukup banyak. Hal ini memberikan layanan yang cukup lengkap bagi penggunanya.

\section{Database}

Basis data (database) adalah kumpulan data yang disimpan secara sistematis di dalam komputer yang dapat diolah atau dimanipulasi menggunakan perangkat lunak (program aplikasi) untuk menghasilkan informasi. Pendefinisian basis data meliputi spesifikasi berupa tipe data, struktur data dan juga batasan-batasan pada data yang akan disimpan. Basis data merupakan aspek yang sangat penting dalam sistem informasi karena berfungsi sebagai gudang penyimpanan data yang akan diolah lebih lanjut. Basis data menjadi penting karena dapat mengorganisasi data, menghidari duplikasi data, menghindari hubungan antar data yang tidak jelas dan juga update yang rumit.

Proses memasukkan dan mengambil data ke dan dari media penyimpanan data memerlukan perangkat lunak yang disebut dengan sistem manajemen basis data (database management system DBMS). DBMS merupakan sistem perangkat lunak yang memungkinkan pengguna basis data (database user) untuk memelihara, mengontrol dan mengakses data secara praktis dan efisien. Dengan kata lain, semua akses ke basis data akan ditangani oleh DBMS. DBMS ini menjadi lapisan yang menghubungkan basis data dengan program aplikasi untuk memastikan bahwa basis data tetap terorganisasi secara konsisten dan dapat diakses 
dengan mudah.

Ada beberapa fungsi yang harus ditangani DBMS seperti mengolah pendefinisian data, menangani permintaan pengguna untuk mengakses data, memeriksa sekuriti dan integriti data yang didefinisikan oleh DBA (Database Administrator), menangani kegagalan dalam pengaksesan data yang disebabkan oleh kerusakan sistem maupun media penyimpanan (disk) dan juga menangani unjuk kerja semua fungsi secara efisien. Tujuan utama DBMS adalah untuk memberikan tinjauan abstrak data kepada pengguna. Jadi sistem menyembunyikan informasi tentang bagaimana data disimpan, dipelihara dan juga bisa diakses secara efisien. Pertimbangan efisien di sini adalah rancangan struktur data yang kompleks tetapi masih bisa digunakan oleh pengguna awam tanpa mengetahui kompleksitas strukturnya.

\section{PHP}

PHP adalah bahasa pemrograman script server-side yang didesain untuk pengembangan web. Selain itu, PHP juga bisa digunakan sebagai bahasa pemrograman umum (wikipedia). PHP di kembangkan pada tahun 1995 oleh Rasmus Lerdorf, dan sekarang dikelola oleh The PHP Group. Situs resmi PHP beralamat di HTTP://www.php.net.

\section{MySQL}

$M y S Q L$ adalah sebuah perangkat lunak system manajemen basis data SQL (DBMS) yang multithread, dan multi-user. MySQL adalah implementasi dari system manajemen basisdata relasional (RDBMS). MySQL dibuah oleh TcX dan telah dipercaya mengelola system dengan 40 buah database berisi 10.000 tabel dan 500 di antaranya memiliki 7 juta baris. MySQL AB merupakan perusahaan komersial Swedia yang mensponsori dan yang memiliki $M y S Q L$. Pendiri MySQL AB adalah dua orang Swedia yang bernama David Axmark, Allan Larsson dan satu orang Finlandia bernama Michael "Monty". Setiap pengguna MySQL dapat menggunakannya secara bebas yang didistribusikan gratis dibawah lisensi GPL(General Public License) namun tidak boleh menjadikan produk turunan yang bersifat komersial.

\section{Variabel Penelitian}

Variabel penelitian merupakan atribut - atribut penelitian yang sangat berpengaruh terhadap objek penelitian. Variabel penelitian meliputi variabel terikat dan variabel bebas. Dalam penelitian ini yang menjadi variabel terikat adalah pembuatan website penjualan kerajinan kulit kerang mutiara, sedangkan variabel bebas dalam penelitian ini adalah:

1. Daftar Produk

2. Foto Produk

3. Data Harga Produk

\section{Teknik Pengumpulan Data}

Adapun teknik pengumpulan data dilakukan seperti berikut:

1. Studi Pustaka

Dalam Teknik ini, pengumpulan data dilakukan melalui internet, buku, jurnal dan lain-lain.

2. Observasi

Observasi dilakukan dengan tujuan untuk memperoleh data primer dengan cara turun langsung ke tempat penelitian.

3. Wawancara

Data dapat dikumpulkan dengan melakukan wawancara terhadap pemilik usaha Pondok Mutiara.

\section{Metode Analisa Data}

Metode Analisis Data yang digunakan adalah metode analisis data kualitatif. Analisis data kualitatif adalah upaya yang dilakukan dengan jalan bekerja dengan data, mengorganisasikan data, memilah-milahnya menjadi satuan yang dapat dikelola, mensintesiskannya, mencari dan menemukan pola, menemukan apa yang penting dan apa yang dipelajari dan memutuskan apa yang dapat digunakan dalam pembuatan website.

\section{Alur Penelitian}

Langkah - langkah penelitian yang akan dilakukan oleh penulis dapat dilihat pada deskripsi berikut ini:

1. Observasi awal. Langkah ini merupakan langkah awal untuk mengetahui gambaran dan kondisi perusahaan secara umum dengan cara turun langsung ke perusahaan.

2. Identifikasi masalah dan tujuan. Langkah ini dilakukan agar peneliti lebih memahami masalah yang terjadi secara lebih spesifik dan mampu menetapkan tujuan yang akan dicapai untuk mencari solusi dari permasalahan yang terjadi.

3. Pengumpulan data bahan . Tahap ini dilakukan untuk mengumpulkan variabel - variabel yang dibutuhkan dalam penelitian. Dalam penelitian ini yang menjadi variabel terikat adalah pembuatan website penjualan kerrang mutiara dan variabel bebas adalah data nama, jumlah produk kerang mutiara, foto barang produk kerang mutiara, data harga produk kerang mutiara.

4. Pembahasan WordPress. Pada tahap ini disertakan penjelasan tentang WordPress serta komponen-komponen lainnya dalam pembuatan website..

5. Diskusi dengsn pemilik Toko. Pada tahap ini peneliti melakukan diskusi dengan pemilik toko guna dapat mengetahui kebutuhan dan 
keinginan pemilik sebagai acuan dalam mendesain website.

6. Langkah awal untuk pembuatan website. Yaitu, dengan pembelian nama domain dan penyiapan hosting.

7. Pemilihan template. Pada tahap ini, penulis memilih template yang sesuai untuk pembuatan website.

8. Desain website. Pada tahap ini penulis mulai mendesain website dengan menambahkan semua data dan bahan yan dibutuhkan dalam pembuatan.

9. Pengujian. Penulis menguji apakah website yang sudah dibuat dapat dijalankan atau tidak.

10. Pelatihan Admin. Penulis memberikan pelatihan kepada pemilik atau orang yang ditugaskan sebagai admin agar dapat merawat dan mengoperasikan website dengan baik.

11. Kesimpulan dan saran. Bagian ini dimaksudkan untuk menjawab tujuan penelitian dengan memberikan solusi masalah pada Pondok Mutiara.

Alir penelitian desain web-site penjualan kerajinan kulit kerang mutiara pada Pondok Mutiara dapat dilihat pada gambar 1 :

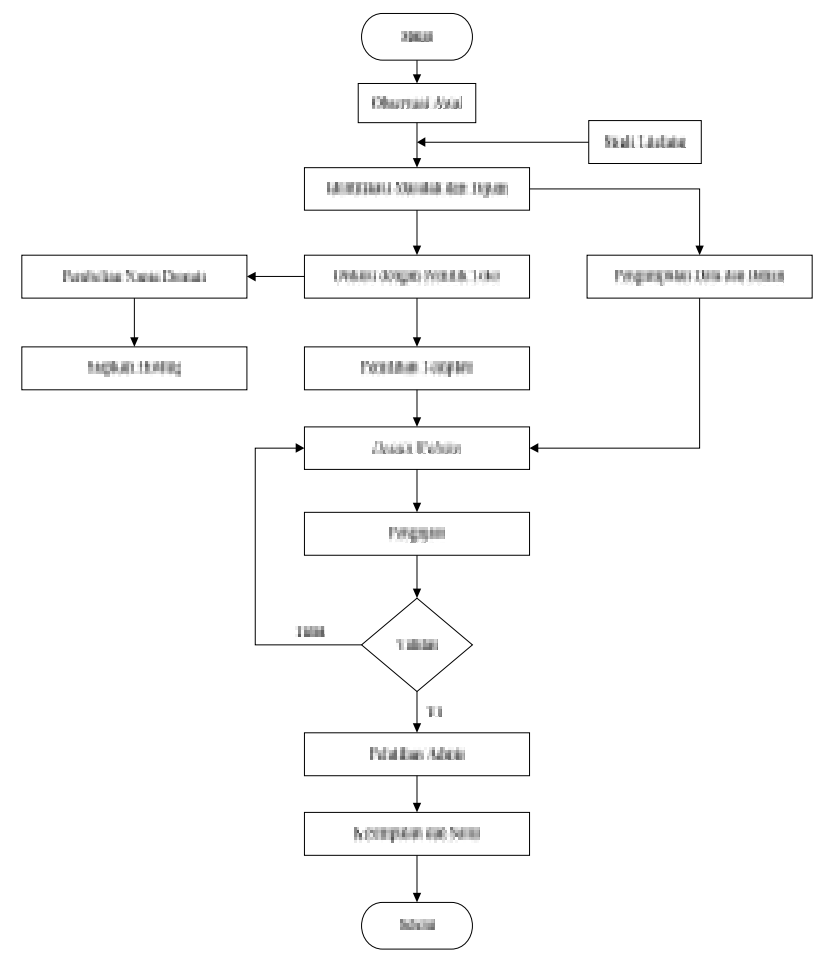

Gambar 1. Flow Chart Penelitian

\section{HASIL DAN PEMBAHASAN}

\section{Analisis Sistem yang Sedang Berjalan}

Berdasarkan Hasil Observasi dan Wawancara di Pondok Mutiara sistem penjualan yang dilakukan bisa dikatakan cukup kuno/ketinggalan zaman dikarenakan belumlah menggunakan teknologi informasi melalui internet seperti facebook, instagram dan yang lainnya. Penyampaian produk kepada pelanggan seperti promosi hanya dilakukan jika ada pamreran yang diselenggarakan oleh pemerintah kota.

Poses penjualan hanya dapat dilkukan jika pelanggan datang berbelanja langsung ke lokasi toko Pondok Mutiara.

\section{Kelemahan Sistem Lama}

1. Trasanksi yang dilakukan masih harus secara langsung.

2. Sistem pomosi tegolong sangat kecil karena hanya mengandalakan pameran yang diselenggarakan pemeintah kota.

3. Infomasi mengenai produk hanya bisa didapatkan jika langsung berkunjung ke lokasi toko Pondok Mutiara.

\section{Desain Web}

Desain web Pondok Mutiara dibuat bertujuan untuk memudahkan pembeli atau kustomer dan pelanggan serta masyarakat pada umumnya dalam mendapatkan informasi mengenai produk Pondok Mutiara, cukup dengan cara membuka website, informasi mengenai produk Pondok Mutiara dapat dilihat dengan baik dan jelas.

Desain web ini dibuat disesuaikan dengan kebutuhan dan keinginan daripada pemilik toko Pondok Mutiara. Untuk itu dalam merancang website ini, penulis melakukan tes FGD (Focus Group Discussion) untuk mengetahui kebutuhan dan keinginan daripada pemilik Pondok Mutiara yang nantinya akan digunakan sebagai bahan acuan dalam desain web yang akan dibuat. Untuk itu, Tes FGD yang dilakukan haruslah ikut disertakan pemilik Pondok Mutiara. Penulis melakukan tes FGD sebanyak dua kali.

$F G D$ pertama dilakukan pada tanggal 8 Januari 2018 bertempat pada toko Pondok Mutiara. Peserta dari diskusi yang dilakukan berjumlah 4 orang termasuk pemilik toko. Berdasarkan hasil diskusi dapat diperoleh beberapa kesepaktan sebagai beikut

1. Website yang dibuat menggunakan jasa $C M S$ Wordpress karena lebih mudah bagi admin untuk mgenglolah website tersebut.

2. Desain yang dibuat haruslah sederhana.

3. Poses pembayaran yang digunakan dalam pembelian produk yaitu transfer antar bank.

4. Menu yang dibutuhkan yaitu home, shop, chart, my account, dan checkout.

5. Menu home dibuat untuk menampilkan pos-pos terbaru.

6. Menu Shop dibuat untuk menampilkan produkpoduk yang dijual Pondok Mutiara.

7. Menu Chart menampilkan poduk-poduk yang sudah dipilih untuk nantinya dipesan. 
8. Menu My Account dibuat untuk melakukan proses $\log$ in dan registasi pengunjung atau pelanggan.

9. Menu Checkout berisi form yang perlu diisi untuk melakukan pemesanan.

10. Lokasi toko, alamat e-mail, dan nomor telephone di tampilkan pada bagian paling atas halaman web.

11. Tedapat kolom komentar terbaru pada bagian bawah web

12. Harga yang dicantumkan pada produk adalah harga asli pada toko tersebut

$F G D$ kedua dilakukan pada tanggal 16 Mei

2018 betempat pada Pondok Mutiara. Peserta dari diskusi berjumlah 3 orang termasuk pemilik toko. Berdasarkan hasil diskusi dapat diperoleh beberapa kesepakatan sebagai berikut :

1. Warna desain yang digunakan dalam website yaitu perpaduan hitam dan putih disesuaikan dengan warna latar dari produk.

2. Stock dari produk haus ditampilkan.

3. Widget yang digunakan yaitu pencarian dan Product Category dibuat pada bagian kanan website.

4. Jasa pengiriman yang digunakan untuk luar kota Ambon yaitu menggunakan jasa pengiriman JNE, TKI, Pos, dsn J\&T

5. Produk dibagi dalam kategori Religious, Nature, dan Other.

6. Halaman Facebook Pondok Mutiara ditampilkan pada bagian kanan bawah halaman website.

\section{Sistem Informasi Website Pondok Mutiara}

Di dalam sistem informasi yang didesain, terdapat tiga pelaku yang berperan di dalamnya sebagai berikut :

1) Admin

Admin adalah orang yang diberikan tanggung jawab untuk mengelolah semua yang menyangkut administrasi dari website itu sendiri mulai dari pengolahan product, pengolahan data order, data member, pembuatan laporan, dan mengatur segala pelengkapan di dalam sistem itu sendiri.

2) Kustomer

Kustomer adalah seseorang yang datang pada toko tertentu secara berkala, yang menjadikan kebiasaan kegiatan membeli barang pada suatu toko tertentu walaupun masih ada toko yang lain, orang yang didekati oleh pemilik toko dengan tujuan agar berbelanja di tokonya lagi di masa mendatang. Sebagai contohnya, orang yang diingat ukuran dan kesukaannya oleh pemilik toko.

3) Pengunjung

Pengunjung adalah orang yang hanya sekedar masuk ke halaman website untuk melihat-lihat infomasi dari website tersebut seberti pos-pos tebaru atau produk-produk yang dijual. Tetapi jika pengunjung tersebut merasa tertarik dengan produk yang dijual dan ingin memesannya, pengunjung dapat melakukan proses egistrasi dan bisa beralih menjadi customer

\section{Context Diagram}

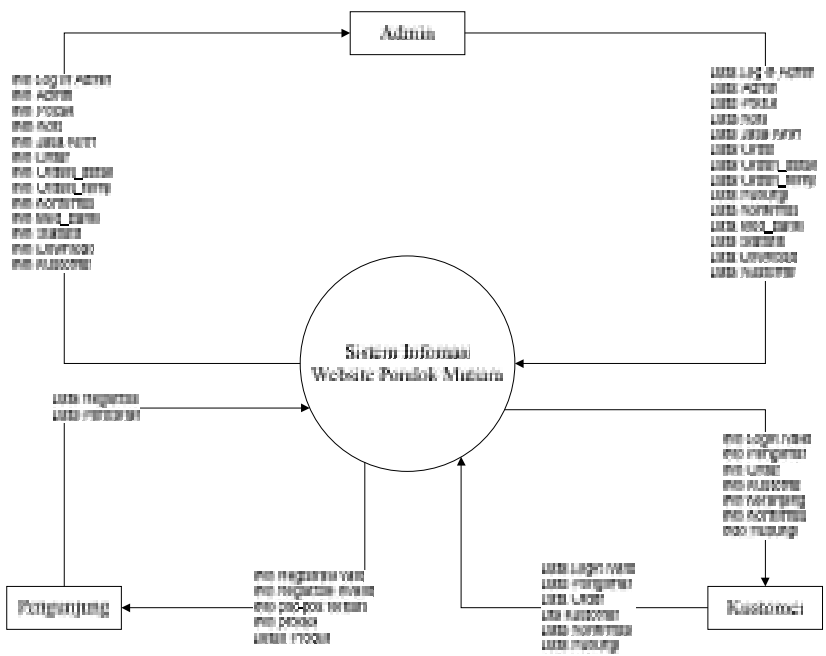

Gambar 2. Context Diagram

\section{DFD Level 0}

Di dalam DFD Level 0 ini terdapat 8 Proses yaitu registrasi, login, kelola data akun, pengolahan data produk, pengolahan data transaksi, pembuatan laporan, pencarian produk, dan pemesanan produk.

1. Proses registrasi

Di dalam proses ini admin menyiapkan form untuk melakukan proses registrasi bagi pengunjung yang ingin menjadi member/kustomer. Form yang harus diisi berisikan alamat $e$-mail daripada kudtomer.

2. Proses Login

Setelah melakukan proses registrasi, pengunjung dapat login akun kapan saja. Login diwajibkan karena jika tidak melakukan proses login kustomer tidak dapat melakukan proses pemesanan produk.

3. Kelola Data Akun.

Di dalam proses ini, akun setiap setiap member akan dikelolah sendiri seperti pengisian biodata umum dan sebagainya. Dalam proses pengelolaan data akun ini, admin memiliki hak untuk menyunting atau menghapus akun member yang sudah terdaftar.

4. Pengolahan Data Produk

Dalam proses ini admin akan mengelolah produk yang dijual seperti menambahkan produk, menyunting produk dan menhapus produk.

5. Pengolahan data transaksi 
Di dalam proses ini admin menyiapkan intruksi untuk melakukan transaksi, kustomer juga dapat mengirim langsung bukti transaksi kepada admin.

6. Pembuatan Laporan.

Pada proses ini admin bertanggung jawab untuk membuat laporan administrasi website seperti jumlah pengunjung, member, dan laporan tentang transaksi yang dilakukan baik produk yang sudah dikirim maupun produk yang belum dikirim.

7. Pencarian Produk

Ini adalah proses dimana pengunjung/kustomer mengecek produk-produk apa saja yang ada pada website.

8. Pemesanan Produk

Ini adalah tahap dimana kustomer memesan produk.

DFD Level 0 dapat dilihat pada gambar 3

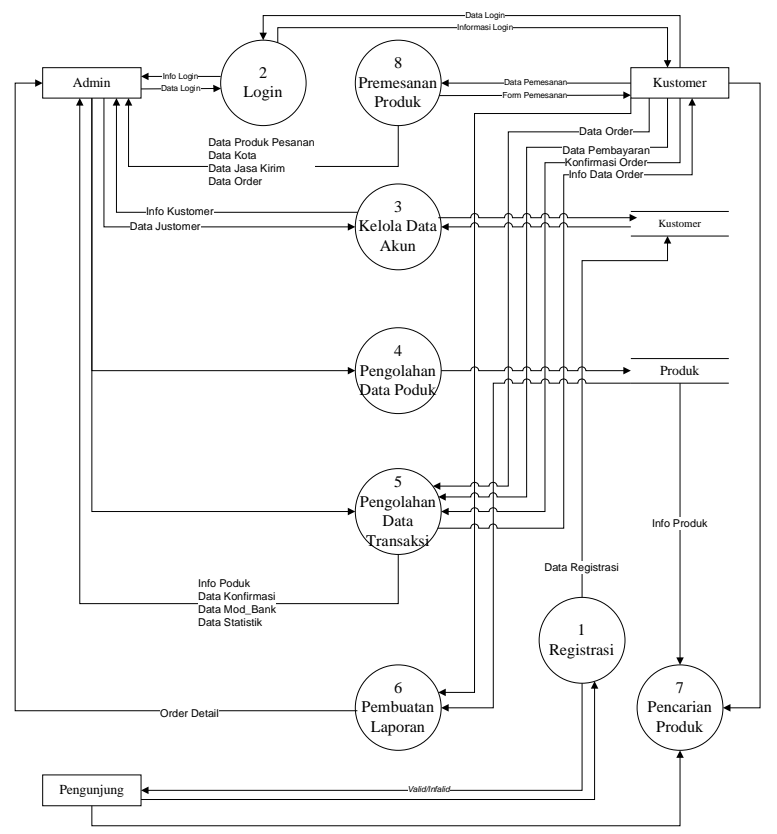

Gambar 3. DFD Level 0

\section{DFD Level 1 Proses Registrasi}

Pada Proses proses registrasi ini terdapat dua proses yaitu pengisian form registrasi dan pengisian biodata akun.

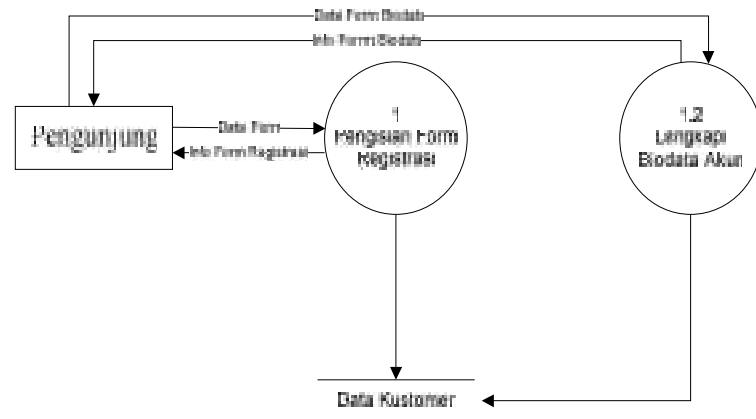

Gambar 4. DFD Level 1 Poses 1 (Proses Registrasi)

1. Pengisian Form Registrasi
Pada tahap ini pengunjung mengisi data $e$-mail dan password akun.

2. Lengkapi Biodata Akun.

Pada proses ini member melengkapi form yang berisi biodata umum.

DFD Level 1 Proses 1 (Registrasi) dapat dilihat pada gambar 4

\section{DFD Level 1 Proses 2 (Pengolahan Data Produk)}

Pada tahap ini terdapat dua proses yang terjadi, yaitu menyiapkan kategori dan input data produk.

1. Menyiapkan Kategori

Admin membuat kategori yang nantinya akan memudahkan kustomer dalam memilih produk yang ingin dibelih.

2. Input Data Produk

Pada proses ini, admin melakukan input data produk seperti nama, deskripsi produk, gambar produk, ukuran, dan harga.

DFD Level 1 Proses 2 (Pengolahan Data Produk) dapat dilihat pada gambar 5

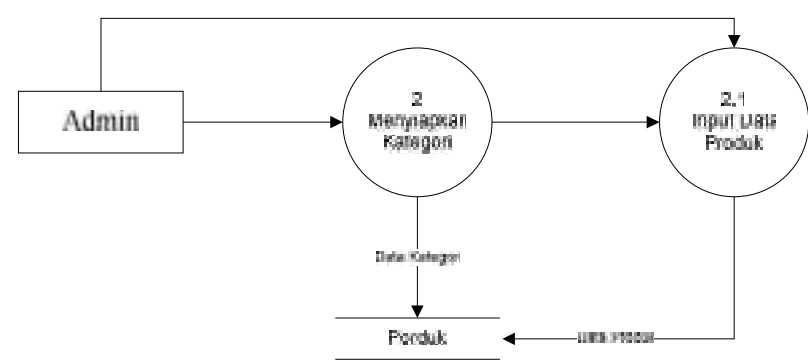

Gambar 5 DFD Level 1 Proses 2 (Pengolahan Data Produk)

\section{DFD Level 1 Proses 3 (Proses Pemesanan Produk)}

Pada tahap ini terdapat dua proses yaitu tambahkan produk ke chart, pengisian form pemesanan, dan pilih jasa pengiriman.

1. Tambahkan Produk ke Chart

Pada proses ini produk yang dipilih oleh kustomer secara otomatis akan ditambahkan ke menu chart/keranjang.

2. Pengisian Form Pemesanan.

Pada Proses ini kustomer diwajibkan mengisi form yang sudah disiapkan untuk memesan produk.

3. Pilih Jasa Pengiriman

Kustomer memilih ingin mengunakan jasa pengiriman barang untuk produk yang sudah dipesan.

DFD Level 1 Proses 3 (Proses Pemesanan) dapat dilihat pada gambar 6 


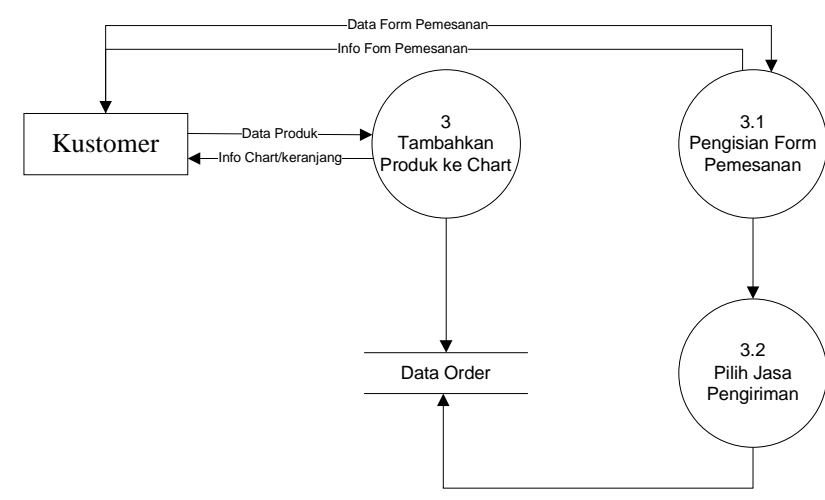

Gambar 6. DFD Level 1 Proses 3 (Proses Pemesanan)

\section{DFD Level 1Proses 4 (Proses Transaksi)}

Pada tahap ini terdapat dua proses yaitu pembayaran dan penyiapan barang.

1. Pembayaran

Pada tahap ini Kustomer melakukan pembayaran transfer ke nomor rekening admin.

2. Penyiapan Barang

Setelah admin menerima konfirmasi pembayaran daripada kustomer, admin kemudian menyiapkan barang untuk dikirim ke alamat kustomer.

DFD Level 1 Proses 4 (Proses Transaksi) dapat dilihat pada gambar 7

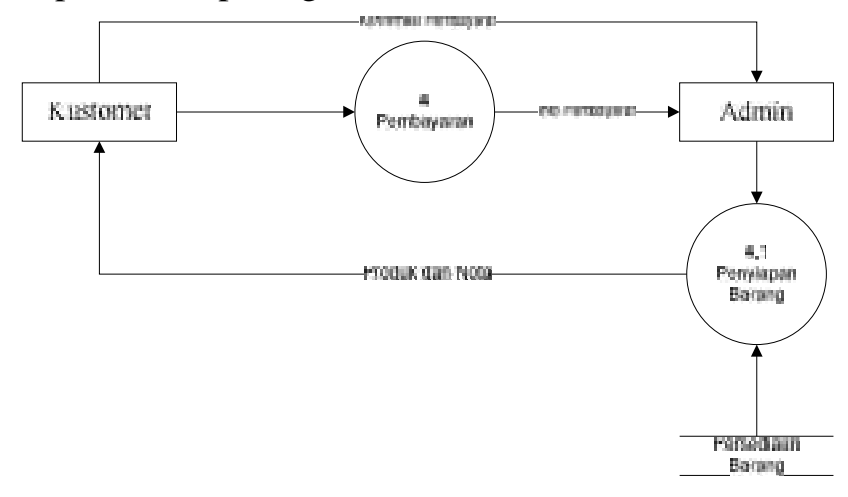

Gambar 7. DFD Level 0 Proses 4 (Proses Transaksi)

\section{Antarmuka Halaman Chart}

Halaman Chart ini menampilkan jumlah produk dan total harga produk yang sudah kita masukan ke keranjang untuk dibeli.

Antarmuka halaman Chart dapat dilihat pada gambar 8

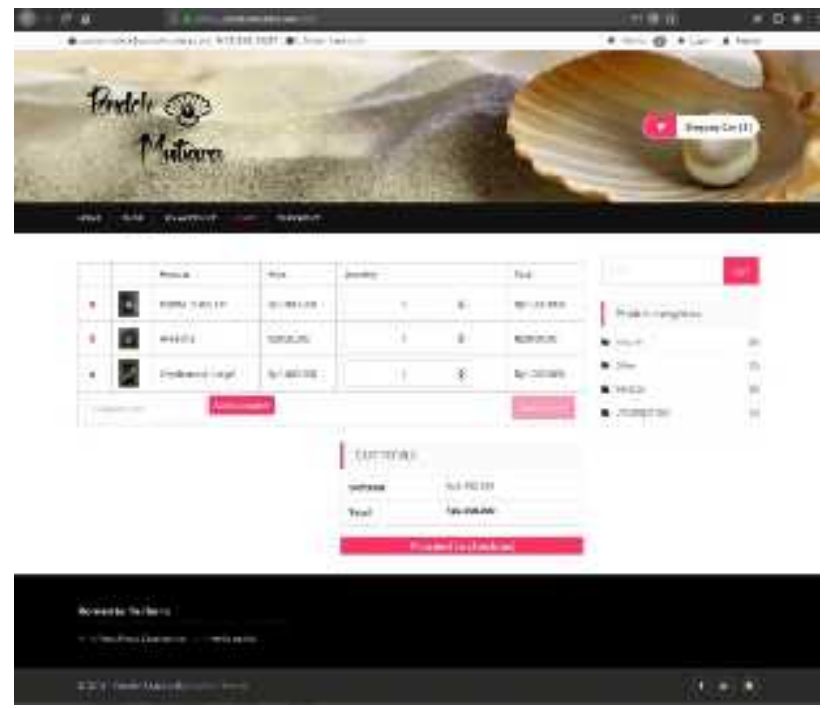

Gambar 8. Antarmuka Halaman Chart

\section{Analisis Sistem Baru}

Fungsi utama dari website Pondok Mutiara adalah :

1 Pos-pos terbaru

Berisi tentang informasi terbaru mengenai produk dan sebagainya dari Pondok Mutiara. Fungsi ini juga dapat berguna untuk melakukan promosi.

2 Chart

Chart adalah menu untuk menampilkan keranjang belanja yang berisi jumlah produk yang telah dipilih untuk dipesan serta total harganya.

3 Cara Pembayaran

Pembayaran dilakukan melalui nomor rekning bank yang sudah ditentukan. Bukti dokumentasi pembayaran akan dikiim ke nomor whatsapp admin.

4 Cara Oder

Berisi cara order poduk dan memilih jasa pengirimannya.

5 Produk

Berisi poduk-produk dari Pondok Mutiara yang akan dijual.

\section{Keunggulan Sistem Baru}

Sistem lama memiliki kelemahan seperti yang tercantum di sub bab kelemahan sistem, sehingga sistem baru harus menutupi kelemahan tersebut. Keunggulan sistem baru yaitu:

1. Informasi mengenai produk dapat dilihat langsung pada website Pondok Mutiara melalui internet tanpa harus datang ke lokasi toko Pondok Mutiara.

2. Pembelian produk dapat dilakukan secara online.

3. Berita baru tentang Pondok Mutiara dapat diakses dengan cepat.

4. Tidak diperlukan biaya tambahan untuk promosi. 
Terdapat beberapa opsi untuk jasa pengiriman beserta total harga untuk ongkos kirim

\section{KESIMPULAN}

Berdasarkan hasil dari penelitian, website yang dibuat menyediakan informasi terkait Pondok Mutiara seperti deskripsi dan harga produk yang dijual. Fitur-fitur dalam website juga sangat mendukung Pondok Mutiara untuk melakukan Promosi. Selain itu dengan adanya website maka konsumen dapat lebih mudah untuk memesan produk dari Pondok Mutiara.

\section{DAFTAR PUSTAKA}

Anonymous, (2006) Rencana Strategik Dinas Perindustrian Kota Ambon

Dinas Koperasi Usaha Mikro, Kecil dan Menengah Provinsi Maluku. (2012) Laporan tahunan

Departemen Perdagangan Republik Indonesia, 2009. Rencana Pengembangan Ekonomi Kreatif Indonesia 2009-2025. Jakarta : Kelompok Kerja Design Power Departemen Perdagangan Republik Indonesia.

Desaindigital. 2013. Cara Mudah Membuat Toko Online dengan WordPress. Jakarta: PT. Elex Media Komputindo

Ginting, Elyzaandayni. 2013. Aplikasi Penjualan Berbasis Web (E-Commerce) Menggunakan Joomla pada Mutiara Fashion. Bandung

Helianthusonfri, Jefferly. 2013. Toko Online Canggih dan Praktis. Jakarta : PT. Elex Media Komputindo

Hidayat, Taufik. 2008. Paduan Membuat Toko Online dengan OS Commerce. Jakarta : PT. TransMedia

Kristianto, Andi. 2014. Jago WordPress. Jakarta : PT. Elex Media Komputindo

P, Anjarkusuma, Dewangga dan Soepeno Bambang. 2014. Penggunaan Aplikasi CMS Wordpress untuk Merancang Website Sebagai Media Promosi pada Maroon Wedding Malang. Malang

PT. Cloud Hosting Indonesia. 2015-2017. Pengertian Web Server dan Fungsinya. https://idcloudhost.com/pengertian-web-serverdan-fungsinya/. $\quad 17$ Desember 2017

Rifa'I, Saifulloh. 2013. Pengertian dan Sejarah MySQL.

https://upyes.wordpress.com/2013/02/06/penger tian-dan-sejarah-mysql/. 25 Januari 2018

Termasmedia.com. 2018. Pengertian Database. http://www.termasmedia.com/lainnya/software/ 69-pengertian-database.html. 25 Januari 2018

Wikipedia. 2017. Informasi. https://id.wikipedia.org/wiki/Informasi. 17 Desember 2017

Wikipedia. 2017. Sistem. https://id.wikipedia.org/wiki/Sistem. 17 Desember 2017

Wikipedia. 2017. Sistem Informasi. https://id.wikipedia.org/wiki/Sistem. 17 Desember 2017

Wikipedia. 2014. Internet. https://id.wikipedia.org/wiki/Internet. 17 Desember 2017

Wikipedia. 2014. Situs Web. https://id.wikipedia.org/wiki/Situs web. 17 Desember 2017

Wikipedia. 2017. WordPress. https://id.wikipedia.org/wiki/WordPress. 17 Desember 2017

Wikipedia. 2017. Perdagangan Elektronik. https://id.wikipedia.org/wiki/Perdagangan_elekt ronik . 25 Januari 2018

Wikibooks. 2017. Pemograman PHP/Pendahuluan/Pengertian PHP. https://id.wikibooks.org/wiki/Pemrograman_PH P/Pendahuluan/Pengertian PHP. 25 Januari 2018 